\title{
Synthesis of GDC-0022
}

Category

Synthesis of Natural

Products and

Potential Drugs

\section{Key words}

GDC-0022
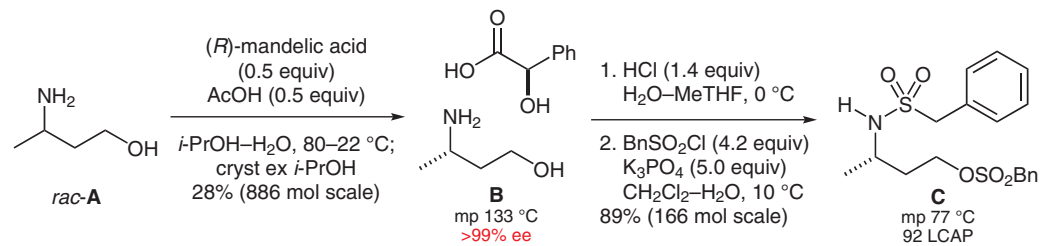

$n-\mathrm{Bu}_{4} \mathrm{NCl}(1.8$ equiv) acetone, $40^{\circ} \mathrm{C}, 15 \mathrm{~h}$

cryst ex $\mathrm{EtOH}-\mathrm{H}_{2} \mathrm{O}$ $94 \%(155 \mathrm{~mol}$ scale $)$ $\mathrm{mp}$
$927^{\circ} \mathrm{C}$<smiles>C[C@H]1CCC(c2ccccc2)S(=O)(=O)N1Cc1cc(F)c(Br)cc1F</smiles>
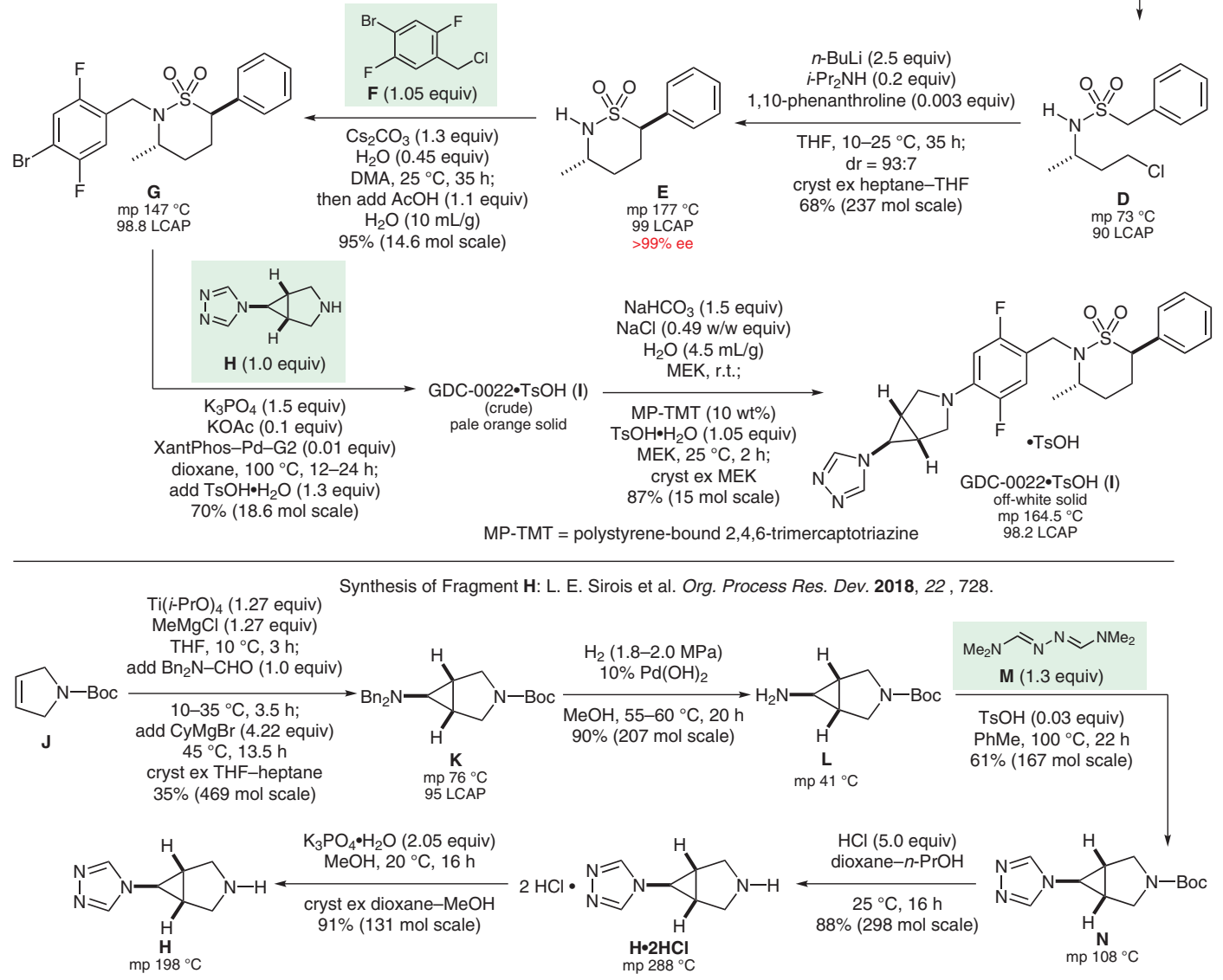

$\mathrm{H} \cdot 2 \mathrm{HCl}$
$\mathrm{mp} 288^{\circ} \mathrm{C}$ $\stackrel{\mathrm{N}}{\mathrm{mp}} 108^{\circ} \mathrm{C}$

Significance: Retinoid-related orphan receptor $\gamma$ (RORC) is a transcription factor and nuclear receptor implicated in proinflammatory cytokine production. GDC-0022 is a RORc inhibitor. The key step in the synthesis depicted was the Buchwald-Hartwig coupling of bromoarene $\mathbf{G}$ with pyrrolidine $\mathbf{H}$ on an $8.0 \mathrm{~kg}$ scale using just $1 \mathrm{~mol} \%$ of catalyst.
Comment: For a multikilogram-scale synthesis of pyrrolidine H, see: L. E. Sirois et al. Org. Process Res. Dev. 2018, 22, 728. Cyclization of D using n-BuLi (2.5 equiv) and diisopropylamine (0.2 equiv) gave sultam $\mathbf{E}$ as a mixture of diastereoisomers that slowly equilibrated to the desired trans-sultam $\mathbf{E}(\mathrm{dr}=93: 7)$.
RORc inhibitor

Buchwald-Hartwig C-N coupling

Kulinkovich cyclopropanation 